\title{
Post-fire vegetation dynamics of a sagebrush steppe community change significantly over time
}

by Sara K. Hanna and Kenneth O. Fulgham

\begin{abstract}
Sagebrush steppe ecosystems of the Intermountain West have experienced a decline over the past 150 years due to changing fire regimes, invasive species and conifer encroachment. Prescribed fire is a common and cost-effective tool used in sagebrush restoration and fuels management. We examined the post-fire succession of a sagebrush steppe community over a nearly 30-year period at two study sites in northeastern California. The long-term nature of this study was particularly significant, as invasive annual grasses dominated the plant community in the years immediately following fire, but native perennial grasses and shrubs successfully out-competed them in the long term. Shrubs were slow to recover but had returned to pre-fire levels by the end of the study period. There was also notable increase in western juniper throughout the study sites, particularly in areas that had not been burned. Our results indicate that mean fire return intervals of 50 years or less would help reduce western juniper encroachment and preserve sagebrush habitat, especially for potentially threatened species such as the sage grouse.
\end{abstract}

$\mathrm{T}$ he sagebrush steppe ecosystem, extending across hundreds of millions of acres throughout the Intermountain Region of the West (the area between the Cascade and Sierra Nevada Mountains to the west and the Rocky Mountains to the east), provides important wildlife habitat as well as economic, recreational and agricultural benefits. Sagebrush steppe habitat has declined in area, continuity and quality over the past century due to overgrazing, spread of invasive species and alterations to natural fire regimes. Human activities, including urban expansion, agriculture, and energy and mining operations, have further fragmented the sagebrush steppe landscape, which has led to loss of habitat for wildlife and a decrease in plant biodiversity and the productivity of the landscape (Anderson and Inouye 2001; Meinke et al. 2009; Miller and Rose 1999; Nelle et al. 2000).

One of the most common tools to restore sagebrush ecosystems is fire (Brown and Smith 2000); prescribed burning encourages biodiversity and the health of ecosystems. In the absence of fire, sagebrush stands become dense and conifers increase, reducing the perennial grass and forb components that constitute an important part of the sagebrush steppe landscape. This causes permanent shifts in the vegetation structure and composition. Fire suppression is a contributing factor in the conifer encroachment into the sagebrush steppe; expanding western juniper (Juniperus occidentalis) ranges have been observed throughout the West (Miller et al. 2005). In general, prescribed fire increases the biomass production of all herbaceous (non-woody) species and reduces woody species cover and the risk of conifer encroachment into the sagebrush rangelands.

One of the greatest concerns about using prescribed burning is the risk of an invasion of exotic species. The most notable invasive species in the sagebrush steppe is cheatgrass (Bromus tectorum). A second concern is that sagebrush is slow to recover following fire and consequently available forage, nesting and brooding habitat for sage grouse (Centrocercus urophasianus) are negatively affected (Baker 2006; Meinke et al. 2009). Sage grouse require a minimum of $20 \%$ sagebrush cover for winter forage and nesting (Beck et al. 2009). The loss and fragmentation of suitable sagebrush habitat has caused sage grouse populations to decline

Online: http://californiaagriculture.ucanr.edu/ landingpage.cfm?article=ca.v069n01p36\&fulltext=yes doi: 10.3733/ca.v069n01p36 
dramatically over the past 30 years (Nelle et al. 2000). For example, sage grouse populations have diminished from more than 40 active leks (breeding grounds) to 1 lek on the Clear Lake National Wildlife Refuge (USDA 2011).

The effect of fire on an ecosystem is dramatically influenced by local environmental factors, including site-specific conditions such as soil and topography, and by land use and management goals. The objective of this study was to produce quantitative data on the long-term vegetation changes (over nearly 30 years) following a prescribed burn in a sagebrush steppe community - the immediate postfire plant communities are often vastly different from those observed decades later.

\section{Study sites and sampling}

The study sites are located in the Clear Lake Hills in Modoc County, California (fig. 1), part of the Doublehead Ranger District in the Modoc National Forest.

The Clear Lake Hills are on the western edge of the national forest, approximately 15 miles (24 kilometers) southeast of Tulelake, and are bordered to the east by the Clear Lake National Wildlife Refuge. In the Clear Lake Hills, the vegetation is primarily mountain big sagebrush (Artemisia tridentata ssp. vaseyana) with an understory of perennial grasses and forbs and scattered western juniper. The climate of the Clear Lake Hills is characteristic of a semi-arid cold desert, with cold winters and relatively warm, dry summers.

In the early 1980s, the U.S. Forest Service selected two sites within the Chandler and Lacy pastures (areas leased to a grazer by the U.S. Forest Service) for prescribed fires. The sites were identified as the Chandler burn and the Lacy burn and are separated by a distance of 2.5 miles ( 4 kilometers) (fig. 1). At the Chandler site, in the late summer of 1980, the U.S. Forest Service conducted a prescribed burn of approximately 700 acres (2.8 square kilometers). The site was divided into four sampling areas - Northeast, Southeast, Center and Northwest - to account for the undulating topography and varying soil textures (fig. 2). Pre-fire sampling was not

Fig 2. Topography of the Lacy site (A), and the Chandler site with the four sampling areas (B). completed by the fire date. At the Lacy site, in early August of the following year, approximately 300 acres (1.2 square kilometers) were burned. The Lacy site had a relatively homogenous landscape, so was not divided into smaller sampling areas, and pre-fire sampling was conducted before the fire date.

The sites had a history of seasonal grazing but were not grazed by any livestock for two growing seasons prior to the burns. Following the burns, they had no cattle grazing for at least 2 years, but there was early-spring grazing by sheep to help control competition from annual grasses, namely, cheatgrass. After 2 years, the sites were grazed every year, in early spring by sheep, in summer by cattle or by cattle and sheep (Brad Reed, U.S. Forest Service Resource Officer (retired), personal communication).

Vegetation sampling. Field data collection consisted of measuring vegetative cover and herbaceous biomass production at each study site. Vegetative cover was measured using the line-intercept method, which is commonly used to measure vegetative cover and composition on rangelands (Canfield 1941).

Permanent transects 100 feet $(30.48$ meters) long were randomly located at both sites prior to

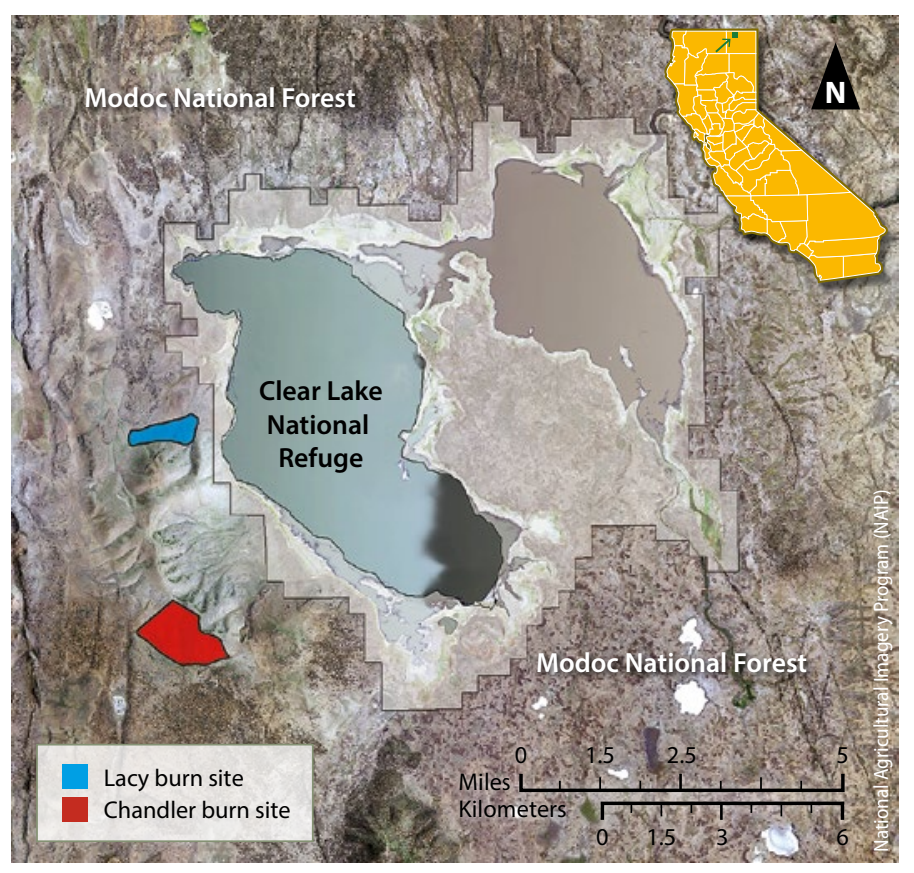

Fig. 1. Location of the study sites in the Clear Lake Hills, Modoc County, California.

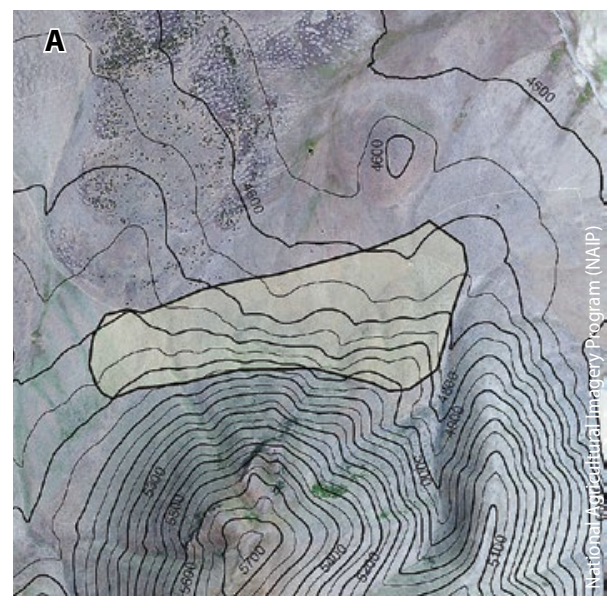

the fires, and measurements were taken along those transects in each sampling year.

Herbaceous biomass production was measured for each plant species using six production plots 1 meter square (10.76 square feet), randomly located along each transect. Within each plot, all aboveground biomass was clipped, bagged and labeled. At the Lacy site, there were 10 transects, and a total of 60 production plots sampled each year. At the Chandler site, there were five transects in each of the four sampling areas, for a total of 20 transects and 120 production plots sampled each year. For analysis purposes, the species-level data collected for both cover and productivity were summarized into the following five morphological groups: 
facilitates rapid growth and seed production on post-disturbance sites (Barbour 1999). Annual grasses, primarily cheatgrass, expanded rapidly following the fires, at both sites. Annual grass cover and productivity increased in the immediate post-fire years but were much greater at the Lacy site than the Chandler site (tables 1 and 2). At the Lacy site, annual grass cover was more than 10 times that of pre-fire levels. At the Chandler site, the majority of annual grasses observed was at the Northwest sampling area (data not shown).

The fact that the Northwest area was the only Chandler area to have a persistent, significant annual grass presence suggests that the prevalence might be explained by local environmental and topographic characteristics. This area was the closest to the road and was immediately adjacent to a gate; the area had been used as a livestock staging area, increasing the risk of soil disturbance and introduction of invasive species. There was also less perennial grass and forb cover in the Northwest area.

Numerous studies, as cited by Knapp (1996), have shown that cheatgrass frequently dominates plant communities following soil disturbances, like fire. By the 10th growing season of our study, annual grasses (cheatgrass) were surpassed by perennial grasses at both sites, though there was an anomalous increase in annual grass cover at both sites in the 20th post-fire growing season. After 28 growing seasons at the Lacy site, annual grass cover and productivity levels were significantly lower than the pre-fire levels $(P<0.001)$ (tables 1 and 2).

Native perennial grass cover and productivity generally increased at both sites in the post-fire years but at a slower rate than annual grass cover and productivity. Within two growing seasons following the Lacy burn, perennial grass productivity had surpassed pre-fire levels. It continued to increase at both sites, peaking 10 years after the fires. Perennial grass cover peaked 20 years after the fires. Perennial

\begin{tabular}{|c|c|c|c|c|c|c|c|c|c|c|c|}
\hline & \multirow[b]{2}{*}{ Year } & \multicolumn{2}{|c|}{ Annual grasses } & \multicolumn{2}{|c|}{ Perennial grasses } & \multicolumn{2}{|c|}{ Annual forbs } & \multicolumn{2}{|c|}{ Perennial forbs } & \multicolumn{2}{|c|}{ Shrubs } \\
\hline & & Mean & SE & Mean & SE & Mean & SE & Mean & SE & Mean & SE \\
\hline \multirow[t]{7}{*}{ Lacy site } & 1981 (Pre-fire) & 1.41 & 0.18 & 6.43 & 0.64 & 0.08 & 0.05 & 0.66 & 0.19 & 28.48 & 1.12 \\
\hline & 1982 & 3.82 & 0.42 & 2.71 & 0.29 & 1.46 & 0.16 & 0.87 & 0.29 & 0.00 & 0.00 \\
\hline & 1983 & 11.47 & 1.20 & 3.98 & 0.49 & 1.23 & 0.10 & 2.54 & 1.17 & 0.08 & 0.03 \\
\hline & 1984 & 18.73 & 2.10 & 5.03 & 0.51 & 1.11 & 0.08 & 1.18 & 0.64 & 0.16 & 0.05 \\
\hline & 1991 & 3.38 & 0.31 & 13.23 & 0.54 & 0.58 & 0.03 & 0.83 & 0.26 & 1.47 & 0.37 \\
\hline & 2001 & 6.91 & 0.85 & 13.17 & 0.69 & 1.10 & 0.08 & 3.57 & 0.45 & 14.72 & 1.90 \\
\hline & 2009 & 0.23 & 0.04 & 8.23 & 0.74 & 0.15 & 0.05 & 3.64 & 0.52 & 27.81 & 2.55 \\
\hline \multirow[t]{6}{*}{ Chandler site } & 1981 & 0.81 & 0.43 & 6.17 & 1.33 & 2.21 & 1.75 & 2.90 & 1.00 & 0.02 & 0.05 \\
\hline & 1982 & 6.74 & 3.04 & 9.31 & 0.22 & 0.77 & 1.94 & 2.99 & 1.55 & 0.08 & 0.14 \\
\hline & 1983 & 5.95 & 2.33 & 11.43 & 0.74 & 2.42 & 3.85 & 6.70 & 2.27 & 0.55 & 0.58 \\
\hline & 1990 & 4.61 & 1.92 & 16.36 & 1.08 & 2.30 & 1.39 & 4.22 & 1.51 & 3.83 & 2.24 \\
\hline & 2000 & 6.18 & 4.02 & 18.68 & 1.44 & 2.27 & 1.46 & 5.50 & 3.69 & 12.42 & 5.09 \\
\hline & 2009 & 0.61 & 0.35 & 11.73 & 0.51 & 1.05 & 1.44 & 4.29 & 1.89 & 19.76 & 4.97 \\
\hline
\end{tabular}

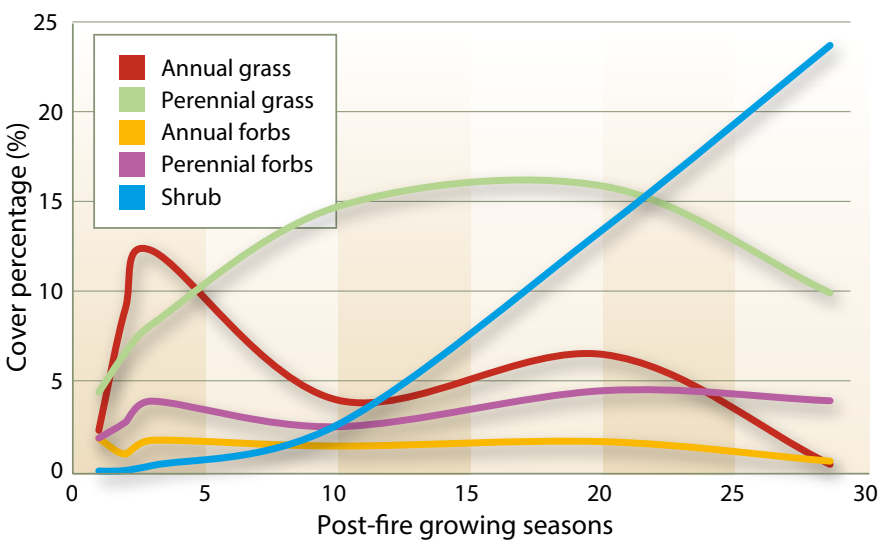

Fig. 3. Mean percentage of vegetative cover at the Lacy and Chandler sites over $\mathbf{2 8}$ growing seasons, by morphological group.

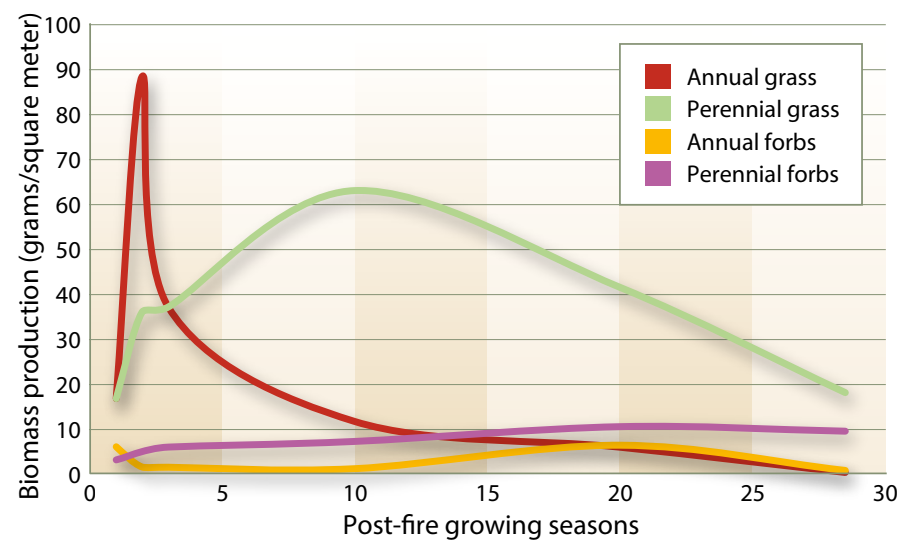

Fig. 4. Mean herbaceous biomass production, in grams per square meter, at the Lacy and Chandler sites. 
grass biomass production increases rapidly due to the release of competitive pressure, while density and cover take longer to recover (Bunting 1985).

In 2009, perennial grass cover and productivity at the Lacy site were still significantly greater than the pre-fire levels there $(P=0.05$ and $P=0.04)$. The recovery and health of the perennial grasses support existing research indicating that many native perennial grasses in mountain sagebrush communities respond positively to fire, with increasing cover and productivity (Ellsworth and Kauffman 2010; Wright 1985). Our data confirms that the native perennial grasses in these plant communities are resilient and capable of withstanding the competitive pressures of cheatgrass.

Annual and perennial forb productivity and vegetative cover fluctuated throughout the sampling period, especially at the Chandler site (data not shown). As observed with the annual grasses, annual forbs are well adapted
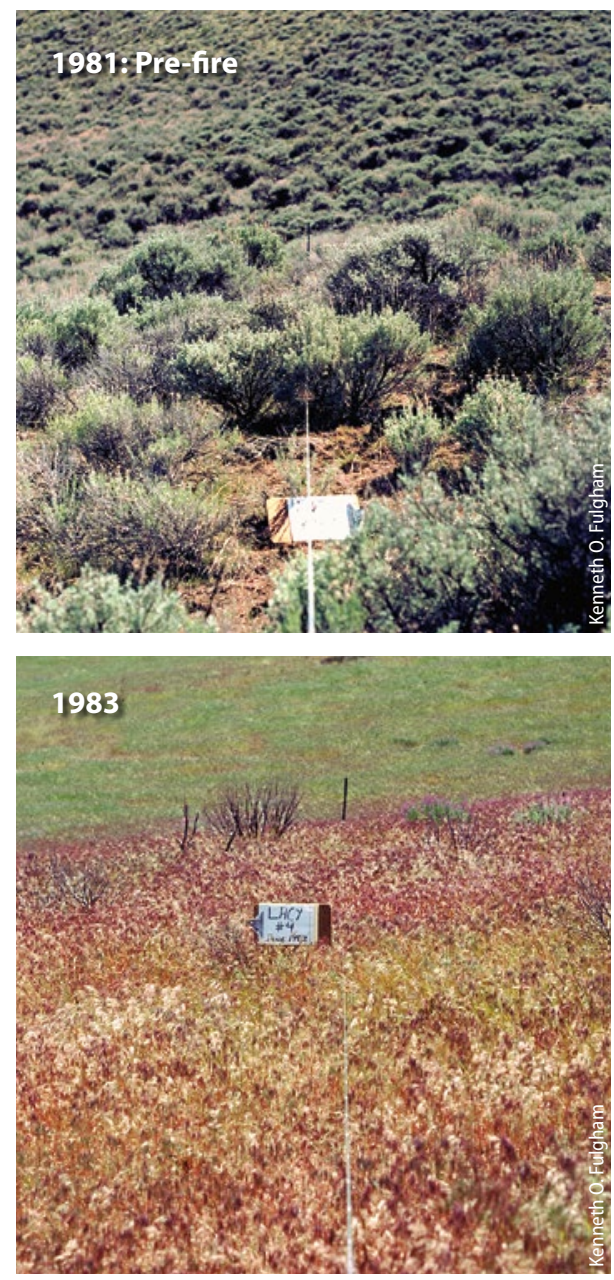

to establish following disturbances and can quickly dominate an area. Perennial forb cover and productivity generally increased at both sites following the fires, suggesting that fire is not detrimental to perennial forbs. Perennial forbs generally fared well in the post-fire plant community, when shrub-dominated competition was removed by the fire. Most of the perennial forbs of the area have belowground growing tissues that allow protection from fire and quick resprouting (Sugihara et al. 2006).

Sagebrush and shrubs. Fire effectively eliminated all shrub cover, and recovery was slow, with only minimal shrub cover observed until 10 to 20 growing seasons after the fire (fig. 5). Early shrub cover was mostly rabbitbrush species, which are avid sprouters and capable of rapid recovery following fire (Sugihara et al. 2006). Mountain big sagebrush re-establishment, however, is entirely dependent on the germination of unburned seeds (Sugihara et al. 2006).
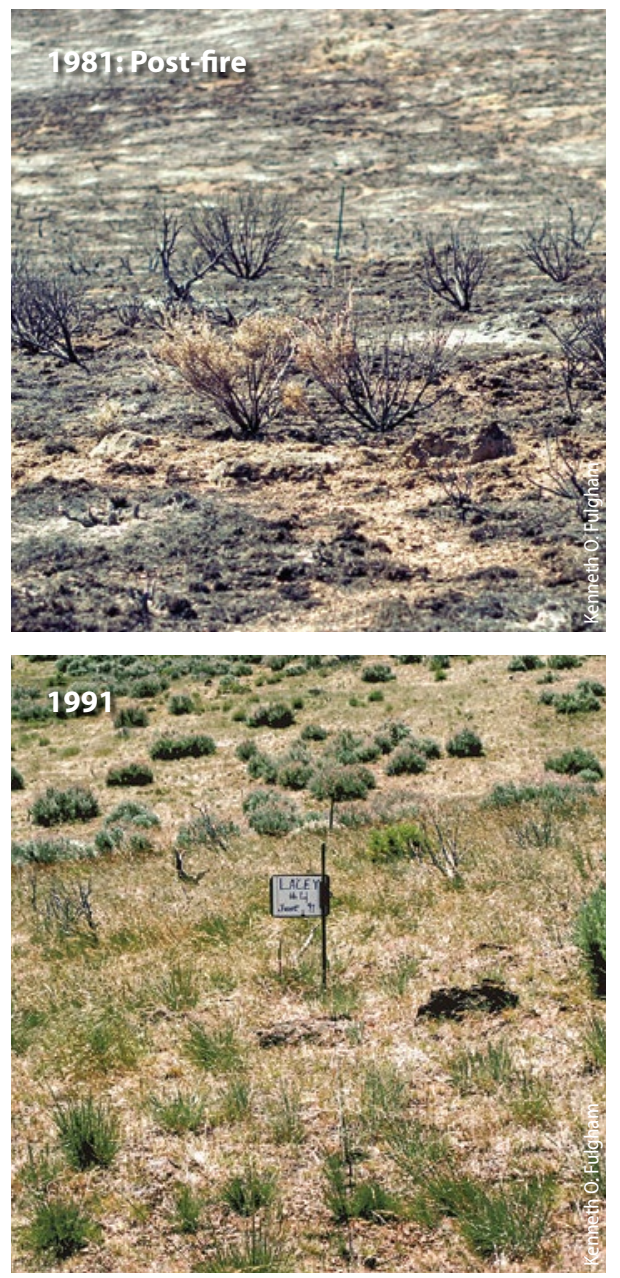

By 2009, sagebrush cover was equivalent to the pre-fire level at the Lacy site, about $30 \%(P=0.54)$. A comparison in that year of the Chandler (burned) site with the three Chandler control (unburned) areas also confirmed that shrub cover after nearly 30 years was comparable. Shrub recovery rates did not differ significantly among the four Chandler sampling areas or between the Lacy and Chandler sites, which indicates that shrub recovery rates were relatively stable across the study area.

Western juniper. The Intermountain West has seen a dramatic increase in the density and spatial distribution of pinyon and juniper woodlands in the past century. An analysis of the aerial photographs from 1975 (pre-fire) and 2012 confirmed this occurrence (figs. 6 and 7). In pre-fire 1975, the Chandler pasture boundaries (7,000 acres) had approximately 184 acres classified as western juniper. By 2012, the area classified as western juniper had nearly tripled, to
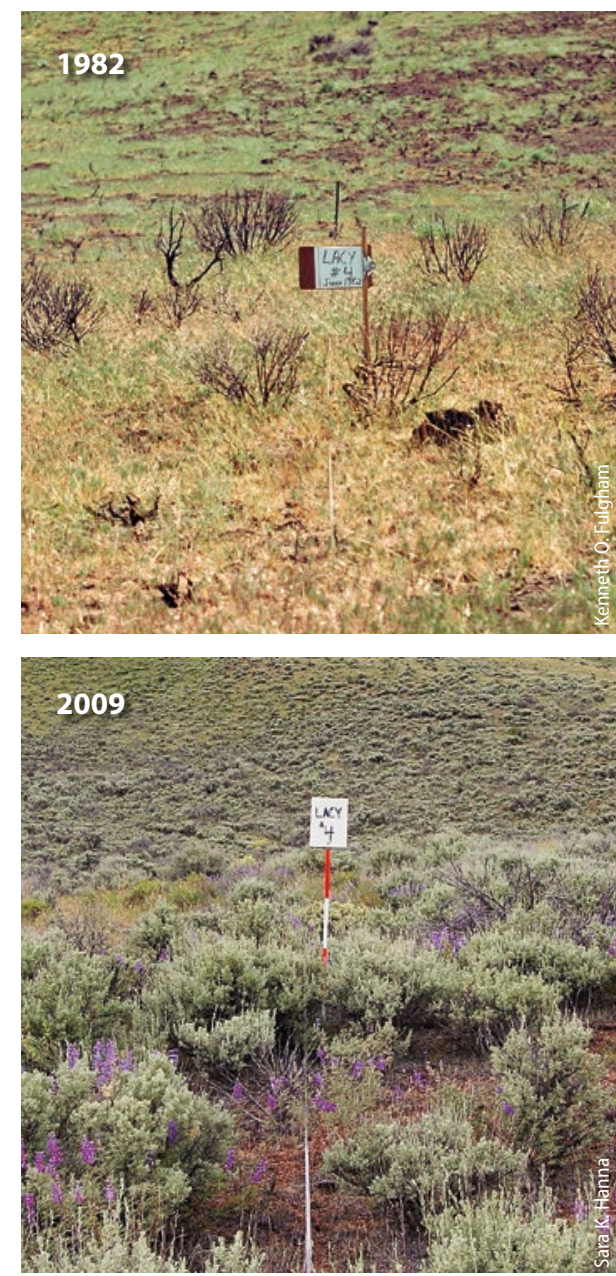

Fig. 5. Vegetation at transect 4 at the Lacy site throughout the monitoring period, from before the fire in 1981 to 2009,28 years later. 
529 acres, outside the burn. Within the Chandler burn site, there was an increase in western juniper but to a much lesser degree, with 2.5 acres classified as western juniper in 1975 and 4.1 acres in 2012. Results were similar in the Lacy pasture (3,200 acres), with western juniper cover doubling between 1975 and 2012 (from 7.8 acres to 16.3 acres). Again within the burn site, there was minimal increase in western juniper, from 0.8 acre in 1975 to 0.9 acre in 2012.

Within the burn sites, western juniper growth was most apparent on the eastern slope in the Chandler Center sampling area. While several of the old-growth junipers survived the fire in that area, many others died and eventually fell over. The western junipers sampled in 2011 for aging were determined to be from a cohort of 13 to 20 years old (mean 15.5 years).

Western junipers do not re-sprout; they regenerate primarily from seed (Miller et al. 2005), and most of the western junipers observed after the fire had established post-fire from seedbanks. Young western juniper trees (less than 50 years old) are not fire tolerant and are easily killed by fire (Miller and Rose 1999). Our research confirms previous study results by Miller and Rose (1999) and Burkhart and Tisdale (1976) that the mean fire return intervals would need to be 50 years or less to reduce western juniper woodland encroachment into mountain big sagebrush communities.

\section{Long-term perspectives}

The long-term nature of this study was particularly important, as the plant communities immediately post-fire, 10 years later and nearly 30 years later each were dramatically different. Invasive annual grasses dominated the plant community in the years immediately following the fires, but native perennial grasses overtook the annual grasses in the long term. Perennial grass and forb recovery was robust at both burn sites.

Estimations of sagebrush recovery have varied widely (25 to 100 years), depending on the sagebrush subspecies and environmental conditions (Sugihara et al. 2006). This study confirms that while sagebrush is slow to re-establish, it can recover to pre-fire levels in approximately 30 years, especially at mesic, productive sites like the Clear Lake Hills. The rate of sagebrush recovery is of particular

\section{Invasive annual grasses dominated the plant community in the years immediately following the fires, but native perennial grasses overtook the annual grasses in the long term.}

concern due to the serious decline of sage grouse populations. The slow rate of sagebrush recovery suggests that smallscale mosaic burns, in which relatively small areas of land are burned at varying intervals to create both burned and unburned patches in the landscape, are most appropriate to preserve a variety of available habitat and forage for sage grouse: The unburned areas would maintain

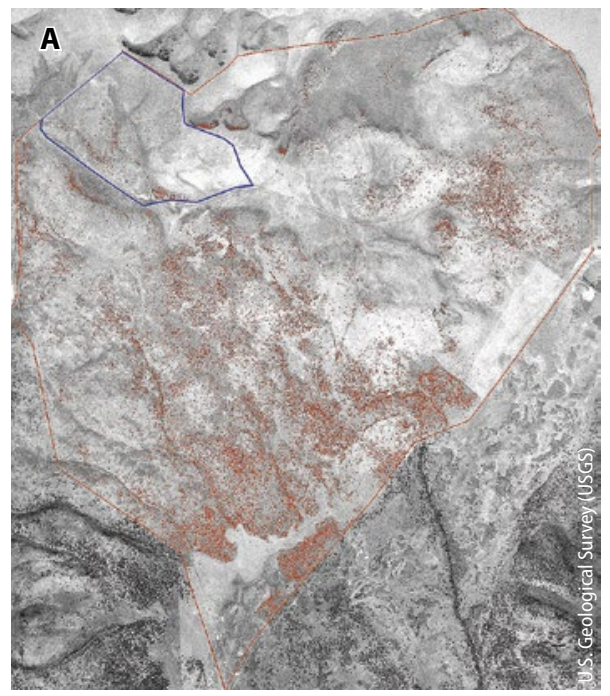

adequate sagebrush cover for nesting, and the burned areas would increase the availability of herbaceous species utilized by the sage grouse and reduce the rate of conifer encroachment.

A significant expansion of western juniper was observed in Lacy and Chandler pastures throughout the monitoring period, resulting in decreasing productivity and diversity of understory vegetation.

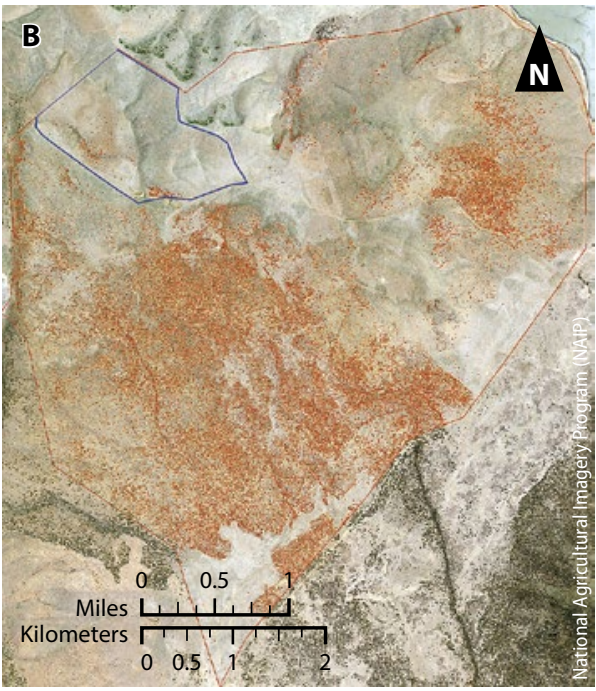

Fig. 6. Aerial photographs from 1975 (A) and 2012 (B) of the Chandler pasture, showing areas classified as western juniper in red. The prescribed fire site is shown in blue.
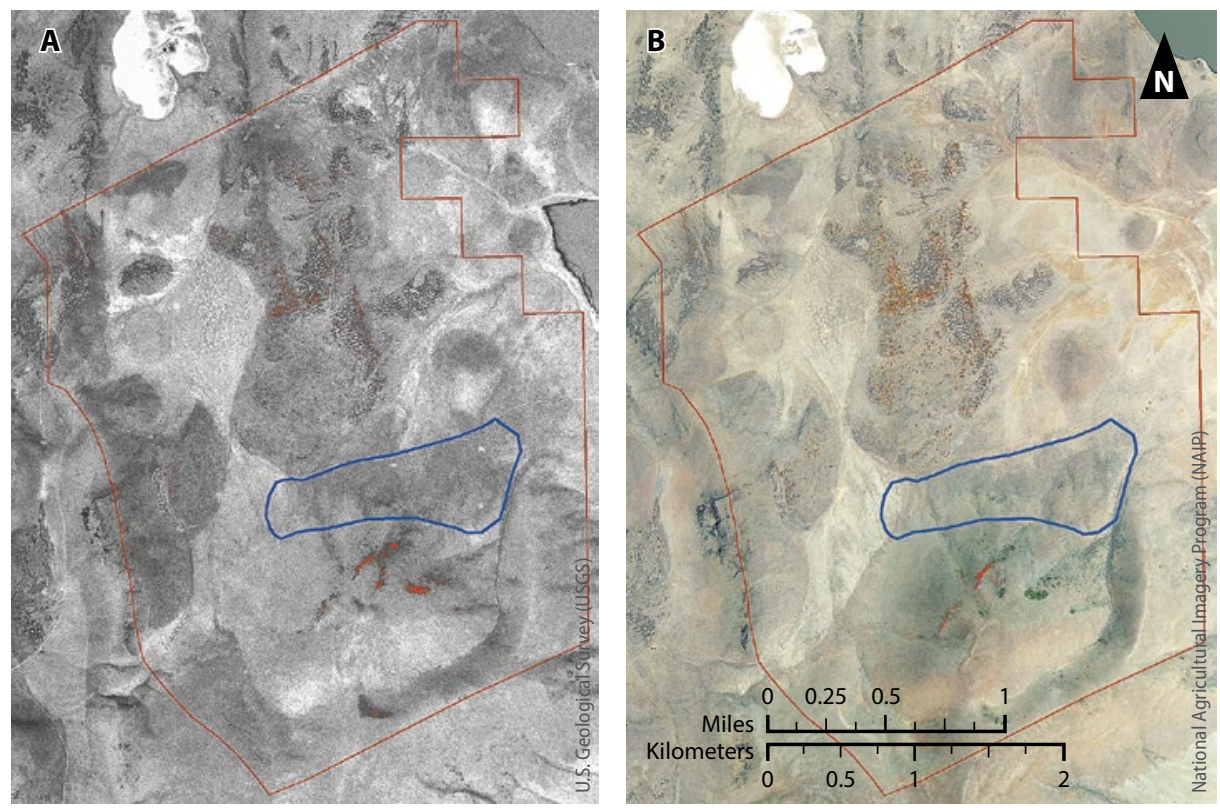

Fig. 7. Aerial photographs from 1975 (A) and 2012 (B) of the Lacy pasture, showing areas classified as western juniper in red. The prescribed fire site is shown in blue. 
In the burn sites, western juniper cover increased, but significantly less so than in the unburned areas. This indicates that a 30- to 40-year fire return interval might reduce western juniper encroachment and maintain a productive and diverse ecosystem.

In terms of the impact of grazing on the post-fire vegetation dynamics, the early sheep grazing may have contributed to the reduction in annual grasses seen at both sites and reduced their persistence and density. The impact of early sheep grazing on the post-fire succession is difficult to quantify without a control treatment. Grazing before a fire can reduce the accumulation of dead plant material around the crowns of grasses, reducing fire residence time and plant mortality (Wright and Klemmedson 1965). Grazing has also been shown to increase the resilience of plant communities following disturbance (Bates et al. 2009). Recent studies have shown that moderate, properly administrated grazing does not hinder the post-fire recovery of herbaceous plants in sagebrush steppe (Bates et al. 2009).

While the post-fire successional patterns were similar at the two sites, there were differences in their trajectories. Shrub recovery rates were stable across the sites, but the recovery rates of herbaceous species were more varied. The spatial complexity of sagebrush steppe communities following fire was especially apparent at the Chandler site, where the four sampling areas varied significantly in their post-fire vegetative cover and

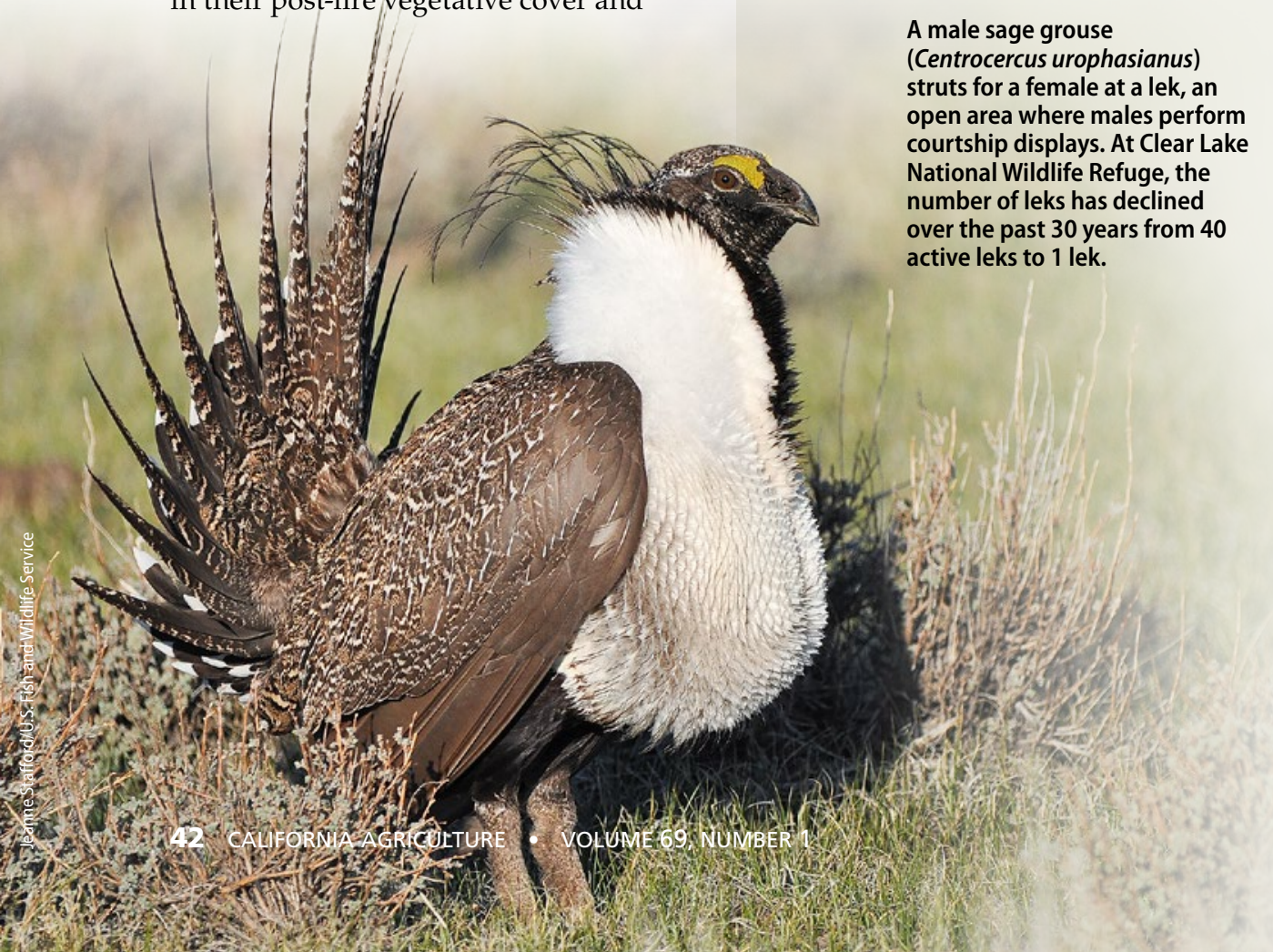

productivity. This confirms that successional patterns are often very sitespecific in sagebrush steppe communities (Bunting et al. 1987; Miller and Rose 1999). Site conditions, including differences in topography and soil characteristics, influence the pre-fire plant communities and therefore the post-fire succession. In mesic, relatively healthy mountain sagebrush communities, native perennial grasses and forbs can respond positively to fire and outcompete invasive annual species. Sites that are degraded and have reduced native grass and forb populations prior to fire may have slower post-fire recovery times and be at the greatest risk for annual grass invasion. While our study confirms a degree of variability in the post-fire vegetation dynamics, the rates of sagebrush recovery were consistent

\section{References}

Anderson JE, Inouye RS. 2001. Landscape-scale changes in plant species abundance and biodiversity of a sagebrush steppe over 45 years. Ecol Monogr 71(4):531-56.

Baker WL. 2006. Fire and restoration of sagebrush ecosystems. Wildlife Soc B 34(1):177-85.

Barbour MG. 1999. Terrestrial Plant Ecology. Menlo Park, CA: Benjamin/Cummings. 668 p.

Bates JD, Rhodes EC, Davies KW, Sharp R. 2009. Postfire succession in big sagebrush steppe with livestock grazing. Rangeland Ecol Manag 62(1):98-110.

Beck JL, Connelly JW, Reese KP. 2009. Recovery of greater sage-grouse habitat features in Wyoming 17(3):393-403.

Brown JK, Smith JK. 2000. Wildland Fire in Ecosystems: Effects of Fire on Flora. US Department of Agriculture, Forest Service, Rocky Mountain Research Station, Ogden, UT.

\section{A male sage grouse (Centrocercus urophasianus) struts for a female at a lek, an open area where males perform courtship displays. At Clear Lake National Wildlife Refuge, the number of leks has declined over the past 30 years from 40 active leks to 1 lek.} big sagebrush following prescribed fire. Restor Ecol across the sites at approximately 30 years. Therefore, agency land managers, scientists and others will find this information useful in forecasting post-fire vegetation re-establishment and recovery, and in determining whether or not prescribed fire is suitable for a given sagebrush community. This is particularly relevant for management of rare, threatened and endangered species. CA

S.K. Hanna is Lecturer in the Department of Forestry and Wildland Resources at Humboldt State University; K.O. Fulgham is Emeritus Professor of Rangeland Resource Science in the Department of Forestry and Wildland Resources at Humboldt State University.

This work was supported by USDA National Institute of Food and Agriculture McIntire-Stennis funds and by U.S. Forest Service funds.

Bunting SC. 1985. Fire in sagebrush-grass ecosystems: Successional changes. In: Sander K, Durham J (eds.). Rangeland Fire Effects: A Symposium. Idaho State Office, USDI-Bureau of Land Management, Boise, ID. p 7-11.

Bunting SC, Kilgore BM, Bushey CL. 1987. Guidelines for Prescribed Burning Sagebrush-Grass Rangelands in the Northern Great Basin. US Department of Agriculture, Forest Service, Intermountain Research Station, Ogden, UT.

Burkhart JW, Tisdale EW. 1976. Causes of juniper invasion in Southwestern Idaho. Ecology 57(3):472-82.

Canfield RH. 1941. Application of the line intercept method in sampling range vegetation. J Forest 39(4):388-94.

Ellsworth LM, Kauffman JB. 2010. Native bunchgrass response to prescribed fire in ungrazed mountain big sagebrush ecosystems. Fire Ecol 6(3):86-96.

Knapp PA. 1996. Cheatgrass (Bromus tectorum L) dominance in the Great Basin Desert: History, persistence, and influences to human activities. Global Environ Chang 6(1):37-52

Meinke CW, Knick ST, Pyke DA. 2009. A spatial model to prioritize sagebrush landscapes in the Intermountain West (U.S.A.) for restoration. Restor Ecol 17(5):652-9.

Miller RF, Bates JD, Svejcar TJ, et al. 2005. Biology, Ecology, and Management of Western Juniper (Juniperus. occidentalis). Agricultural Experiment Station Tech Bulletin, Oregon State University, Corvallis, OR. 77 p. Miller RF, Rose JA. 1999. Fire history and western juniper encroachment in sagebrush steppe. J Range Manage 52(6):550-9.

Nelle PJ, Reese KP, Connelly JW. 2000. Long-term effects of fire on sage grouse habitat. J Range Manage 53(6):586-91.

Sugihara NG, Van Wagtendonk JW, Shaffer KE, et al. 2006. Fire in California's Ecosystems. Berkeley, CA: University of California Press. 596 p.

USDA. 2011. Efforts to Improve Sage Grouse Habitat in California. http://blogs.usda.gov/2011/11/18/efforts-toimprove-sage-grouse-habitat-in-california/.

Wright HA. 1985. Effects of fire on grasses and forbs in sagebrush-grass communities. In: Sanders K, Durham J (eds.). Rangeland Fire Effects. Idaho State Office, Bureau of Land Management, Boise, ID. p 12-26.

Wright HA, Klemmedson JO. 1965. Effect of fire on bunchgrasses of the sagebrush-grass region in southern Idaho. Ecology 46(5):680-8. 